\title{
Foster care from the perspective of Roma foster parents in Roma settlements in Međimurje county
}

\author{
Mateja Krčar \\ Centre for social welfare Čakovec
}

Maja Laklija

University of Zagreb, Faculty of Law, Study centre for social work E-mail: maja.laklija@pravo.hr

\begin{abstract}
Foster care is a form of care for children who can't receive appropriate care in their primary family. It's an alternative to institutional care for children and its advantage is the family environment. The aim of this research was to gain an insight into experiences of Roma foster parents $(\mathrm{N}=7)$ with providing foster care in Roma settlements. The results of this research show that Roma foster parents decided to become foster care providers because of their desire to provide an appropriate care for children, the existence of conditions for providing foster care and their experience with foster care through life. Hindering factors in providing foster care are the reactions of local people, behaviour of the biological parents of children, children's behaviour and life in the Roma settlement due to their specific way of life. Empowering factors in providing foster care are: social support, so-called emotional "effects" of foster care on the foster parents as well as life in the Roma settlement due to preservation of the culture, language and identity. Practical implication of the research is a deeper understanding of this subject area, and the results, besides being used to consider future research, also provide guidelines for practical action for improving the quality of care for Roma children in foster care and supporting Roma foster parents in accordance with their tradition and culture.
\end{abstract}

Key words: foster care, children, social care, Roma families, Roma settlements

\section{Introduction}

Children in Roma families often grow up in more difficult conditions and do not have the same possibilities of being equally represented in the society. Growth and development in primary families can be jeopardised for some Roma children because of their unfavourable living conditions due to which the social welfare system must react. The Convention on the Rights of the Child (State Institute for the Protection of Maternity and Youth, Zagreb, 2001) states that one of the child's rights is the right to replacement assistance by placing the child in a foster family, by adoption or by placing the child in a child welfare institution. It is noticeable that children of Roma origin have less chance of placement in foster families and there is also not enough Roma foster families, so those children often stay longer in institutional care in relation to other children (Kennedy, Kukk \& Mansens, 2010). Likewise, Roma children often get unduly categorised as children with intellectual disabilities which makes their fostering and adoption more challenging (Anghel, Herczog \& Dima, 2013). On the other hand, taking into account the importance of a child being able to grow up in its own culture and to build its own cultural identity, we encounter a problem of finding new potential 
Roma foster families that would facilitate it, mostly due to the failure of interested Roma families to satisfy legal prerequisites for getting the permit, as indicated by The National Roma Inclusion Strategy for the 2013 - 2020 period (Government of the Republic of Croatia, 2012). Potential foster families often do not meet the income census, frequently do not complete elementary school education or have elementary school education from a public university. Also, according to the National Roma Inclusion Programme (Government of the Republic of Croatia, 2012), a potential problem in recruiting new Roma foster families is reflected in the Roma settlement infrastructure, calling into question the suitability of foster families from these settlements in providing foster care for a child and co-residents' view of fostering as means of profit. Despite that, social welfare centres find ways of introducing new Roma families into the foster care system. The National Roma Inclusion Programme (Government of the Republic of Croatia, 2012) mentions in the social welfare section precisely the encouragement of the development of foster care in Roma families, especially for placement of children without adequate parental care, which should be continuously implemented by the social welfare centres, NGOs and the Ministry for Demography, Family, Youth and Social Policy.

Republic of Croatia lacks research in the area of foster care conducted on the Roma national minority. Considering the aforementioned and the Plan for de-institutionalisation and transformation of social welfare homes and other legal persons performing social care activities in the Republic of Croatia from 2011 to 2016 (2018) (Ministry of Health and Social Welfare, 2010) that highlights the importance of developing foster care, as well as the need for promoting foster care and finding new foster families, including recruiting foster parents who belong to the Roma national minority, we found it important to examine experiences of foster parents who belong to the Roma national minority and to bring up some topics for further research.

\section{Fostering children who are members of the Roma national minority in some European countries}

Europe notes a noticeable disturbing growth trend in the number of children in institutional care, especially of vulnerable groups of children whose members are also Roma children (Vandekereckhove, 2011, Council of Europe, 2012). Referencing reports of the European Roma Rights Centre, McGaughey, Curran, Fay, Nurse \& Garland (2012) express concern regarding rights and issues pertaining to protection of Roma children in Europe, pointing to, among other things, a large number of Roma children represented in the institutional care system in European countries. ${ }^{1}$ Daugherty Bailey and Schmidt (2014) mention that the reason for this is because the social welfare system still favours institutional care, especially for Roma children. European Network of Ombudspersons for Children [ENOC] (Vandekereckhove, 2011) mentions the problem of lack of data for comparing different EU countries seeing as the majority of EU countries does not collect and/or publish in official reports the data on children's nationality (McGaughey et al., 2012). Furthermore, the exact number

1 Data for Bulgaria says that $50 \%$ to $63 \%$ of children in children's homes are Roma (Council of Europe, 2012; McGaughey et al., 2012). In the Czech Republic this percentage is $33 \%$ according to McGaughey et al. (2012), while the Council of Europe (2012) cites a percentage of $40 \%$ of Roma children. There are $65 \%$ of Roma children in children's homes in Hungary, in Romania $31.8 \%$ while in some regions this percentage reaches up to $80 \%$ (Council of Europe, 2012; McGaughey et al., 2012). Italy has a percentage of $10 \%$ of Roma children in its children's homes while there are $45 \%$ of them in family homes (Council of Europe, 2012). Slovakia has between $70 \%$ and $95 \%$ of Roma children in children's homes, and one of the reasons is placement of children into children's homes for the purpose of education (Council of Europe, 2012). 
of Roma children who are foster care beneficiaries is not known due to the right of parents and children to choose whether to list their nationality or not. Considering the availability of sources regarding this thematic area, below are situations in countries for which data and research were available to the authors.

Smith Rotabi and Hübinette (2017) state that in the 18th century in the Austrian Empire 18000 Roma children were placed in Catholic foster families within the compulsory assimilation project aimed at Roma population and that this example was followed by other European nations. Although the situation is different nowadays in regards to segregation and placement of Roma children into foster care, care-related difficulties regarding Roma children outside of their own families are notable. Despite international criticism and desire for change, the Czech social welfare system categorises Roma children as unfit for foster family care due to the partiality of system towards institutionalisation which is considered as a priority type of care, although the importance of family support and alternative to such type of care is stressed (Daugherty Bailey \& Schmidt, 2014). In order to reduce the number of Roma children in children's homes, Hungary encourages Roma families to participate in foster care education. However, this is a slow process due to unfavourable housing conditions of Roma families which thus do not fulfil foster care conditions, but also due to prejudices of the majority population towards the Roma people (Family, Child, Youth Association, 2014). Prejudices can be recognised in negative attitudes of the majority population towards the Roma people who are described as insincere, aggressive, with bad personal hygiene, without working habits, unemployed, badly educated and prone to crime (Rosenfield, 2010). Ireland has recognised the unacceptability of placing a Roma child into a culturally different environment and the need for adequate foster families for Roma children is highlighted (McGaughey et al., 2012). Romania has recognised, among other things, a problem of high number of Roma children in institutional care where they are exposed to humiliating behaviour, and even to abuse (D'Arcy $\&$ Brodie, 2015). In Romania, one of the conditions for receiving foster care licence is the ability to parent children of different nationalities, primarily that of Roma, which contributes to the quality of providing care (Sirius - Centre for psychological counselling, education and research, 2017). There was a test project conducted in Albania that ensured means and support for kinship fostering for Roma children, but after the withdrawal of funds, project support services were no longer available (D'Arcy \& Brodie, 2015).

Roma children in the institutional care system are more represented than other children, and chances for their adoption or fostering are reduced, among other things because of prejudices, stereotypes and stigmatisation of the Roma population in general (Brook, James \& Barth, 2002; Morgan \& Baron, 2011; Elijaš \& Laklija, 2014; D’Arcy \& Brodie, 2015; Šikić-Mićanović, Ivatts, Vojak \& Geiger-Zeman, 2015). In many European countries (e.g. the Czech Republic, Hungary, Bulgaria, Romania, Italy, Slovakia etc.) there is a noticeable lack of preventive measures of the social welfare system that would respond to the needs of Roma families at risk and that would prevent segregation of children, as well as lack of services for Roma children and families in the community (Council of Europe, 2012). Lack of adequate housing conditions, lack of family planning, poverty and low level of education of parents who migrate in search of work and abandon their children (D'Arcy \& Brodie, 2015), illness of parents, prison or young mothers who abandon their children (Council of Europe, 2012) all contribute to the large number of Roma children in the institutional 
care system. Likewise, children are placed in institutional care for reasons of abuse, social reasons (e.g. poverty, homelessness), education, health condition or development issues, and the reason for slow de-institutionalisation of Roma children is the bias of experts towards institutionalisation (Daugherty Bailey \& Schmidt, 2014). The European Court of Human Rights delivered a judgement determining discrimination of institutionalised Roma children in the Czech Republic, and it is related to their inclusion into groups which work according to customised and special programmes not taking into account their real capabilities (Daugherty Bailey \& Schmidt, 2014).

After children are placed in the care system for children without adequate parental care, they often lose contact with their parents, although they retain all parental rights (D'Arcy \& Brodie, 2015). Children in foster families have a very limited contact with families, and many of them find it quite difficult or even impossible to cultivate their Roma culture and to use Roma language (Committee on the Elimination of Racial Discrimination, 2015). Roma children are thus put in a situation where they lose their ethnic identity and are alienated from their culture and other Roma people (Smith Rotabi \& Hübinette, 2017, Sweeney \& Matthews, 2017). There are very few members of the Roma national minority working at children's homes which represents an obstacle to strengthening ethnic identity of Roma children in institutional care (McGaughey et al., 2012). Regardless whether the children are placed in institutions or foster families, it is necessary to maintain contact between them and their families and ethnic groups to whom they belong (McGaughey et al., 2012; Laklija \& Sladović Franz, 2013, Smith Rotabi \& Hübinette, 2017). O'Higgins (1993) warns that Roma children, who grow up without contact with their culture, adopt values and attitudes of the majority population towards the Roma people which are often negative, which leads to children often not having the possibility to identify with the positive aspects of their culture and that the child, over time, comes to see its cultural identity as a negative one. On one hand, a child is often seen as different in regards to the community s/he lives in, and on the other hand, the Roma population sees him/her as an outsider due to adopted values and lifestyle of the majority population. Society's negative attitude, but also the negative attitude of the child towards its culture can lead to the child's social isolation (Smith Rotabi \& Hübinette, 2017) and a manifestation of socially unacceptable and even criminal behaviour (O'Higgins, 1993). In situations when a child is placed into a foster family from a majority population in order to prevent the aforementioned, it is important to allow contact between fostered children and the Roma community via Roma cultural centres or Young Roma Associations (Committee on the Elimination of Racial Discrimination, 2015). Daugherty Bailey and Schmidt (2014) point to the need for a so-called cultural change in the social welfare system treatment that would result in protection of the Roma children's right to their identity and culture, and that would be realised by widening the support services for children and their parents. Numerous authors (e.g. McFadden \& McNitt, 2008; UNICEF, 2008; Laklija, Blažeka Kokorić \& Žabarović, 2016) underline that education about the importance of fostering and adoption of Roma children is slowly changing their stake in the population of children placed in care outside their own families. 


\section{Fostering children who are members of the Roma national minority in the Republic of Croatia}

Regarding the fostering of Roma national minority children, there is a noticeable lack of data in official reports of the competent ministry seeing as data about the nationality of children or parents is not published. Although fostering of Roma children is not considered specialised, we are dealing with a specific group of children for which, along with a general lack of foster parents within the Republic of Croatia, there are additional difficulties in finding foster families. One could ask why that is so. According to the research of Laklija, Blažeka Kokorić and Žabarović (2016), experts list affiliation with the Roma minority as a reason for difficulties in realising adoption, especially for older children or when this affiliation with the Roma community is combined with other risks (e.g. health problems, behaviour problems in children and other). More specifically, in relation to fostering, i.e., willingness of foster parents to foster a child with specific characteristics (Laklija, 2009), foster women who partook in the research expressed moderate willingness to foster a Roma child $(M=3,78$, std $=1,497)$, that is, most of them answered "I am neither ready or not ready to foster a child from that category". In the aforementioned research, while checking the factorial structure of the Questionnaire for willingness of foster parents to foster a child from a certain category, the particle referring to the Roma children category was projected onto several components and did not have any significant saturation and was not used in further analysis. The reason for this may be providing of socially desirable answers that cover up the real willingness of foster parents to foster a Roma child. Due to a lack of Roma foster families and their placement into institutions or foster families of the majority population, Roma children lose their contact with their mother tongue, identity and/or religion. Listed above is against the child's interests and provisions of the Convention on the Rights ${ }^{2}$ which obliges states parties to respect the right of the child to preserve his or her identity, including nationality, name and family relations as recognized by law. Marčac (2014) lists that foster parents, who are not members of the Roma national minority, face numerous challenges in raising Roma children because they are not familiar enough with the culture and tradition as well with language, and that it is important, in that aspect, to receive assistance from professionals working in social welfare centres.

We have several documents highlighting the importance of promoting and encouraging development of foster care for Roma children, as well as foster care where care providers are of Roma nationality. Thus the National Strategy for the Rights of Children $2014-2020$ in the Republic of Croatia (2014; pages 61,65) underlines, among other things, the necessity "of developing and safekeeping of the child's sense of identity (personal, familial, religious, cultural, ethnic) and affiliation during his or her placement in alternative care by ensuring care in the language the child uses", "ensuring consistent application of measures of professional support and assistance to the family caring for the child by following the interculturality principles and respecting the child's and the family's cultural identity when providing services", as well as "promoting and encouraging foster families to foster Roma children, increasing the number of Roma foster families that fulfil legally prescribed conditions". Some other documents also mention the measure of encouraging

2 Article 8 of the Convention on the Rights of the Child mentions the following: "States Parties undertake to respect the right of the child to preserve his or her identity, including nationality, name and family relations as recognized by law without unlawful interference. Where a child is illegally deprived of some or all of the elements of his or her identity, States Parties shall provide appropriate assistance and protection, with a view to re-establishing speedily his or her identity. "(State Institute for the Protection of Maternity and Youth, Zagreb, 2001). 
development of foster care in Roma families, for example the National Programme for the Roma of the Government of the Republic of Croatia (2003) and the Action Plan for the implementation of the National Roma Inclusion Strategy (2012) that points to the importance of developing foster care for Roma children primarily in Roma families, and encouraging potential Roma families to become foster families. However, it is important to take into account the context of the Roma community because, as mentioned in the text of the strategy, Roma communities look at fostering children in Roma families as a new way of "profit" which is why children are "kidnapped" from families. Vereš (2015a) points to the same thing by saying that Roma foster parents have the experience of being accused in the Roma communities for "ethno-business", i.e., for profiting off their children and are anonymously reported for alleged negligence, neglect and bad behaviour towards fostered children. Vereš (2015b) cites that Roma foster families are aware that their involvement sends a message to other Roma people and to the public saying that persons of Roma nationality can provide quality care to children, at the same time reducing prejudices and stereotypes towards the Roma and also expressing regret about the lack of discussion in public about the Roma who are responsible towards themselves, their family and society.

Žižak (2008) points to the importance of foster care for Roma children in Roma foster families and suggests education and strengthening of interested families (they have to fulfil minimal conditions for becoming foster care providers) in Roma settlements, as well as the importance of participation of family centres in Roma settlements and of implementation of projects related to fostering of Roma children that can be financed from domestic and foreign funds. In accordance with that, Forum for quality foster care and the UNICEF Croatia office (Forum for quality foster care, 2014) started a project called Developing foster care for Roma children We see them differently, we love them equally in Međimurje, Varaždin and Istra counties. Project activities include foster parents' education (especially of those from the Roma communities) and professionals, exchange of experience, individual support for foster parents and raising awareness regarding foster care.

Taking into account the aforementioned, due to the lack of research of foster care regarding fostering of Roma children and availability of foster parents ready to foster a Roma child, as well as a small number of foster parents who belong to the Roma national minority, this area of research was chosen. The largest Roma communities according to the National Roma Inclusion Strategy for the 2013 - 2020 period (Government of the Republic of Croatia, 2012) are situated in the Međimurje County, the city of Zagreb and Osijek - Baranja County, but it can be said that the Roma minority in Croatia is spatially dispersed. Considering the number of foster families who belong to the Roma national minority, especially foster families who live in Roma settlements, Međimurje County was chosen and the research was performed there. Before presenting the research, the following subheading gives a short overview of the state of play regarding child fostering in Međimurje County, with a special emphasis on Roma children. 


\section{Statistical data on the number of children and foster families of Roma nationality in Međimurje County}

Fostering Roma children in Međimurje County is more developed than in the rest of the country. The specificity of Međimurje County is the fact that more and more Roma families apply as potential foster families, but the problem which occurs is related to insufficient education of Roma families needed to gain their status as foster families (Žižak, 2008). In Međimurje County there were one hundred and fifty-three fostered children at the time of the research, of which eighty-six were Roma children (forty-two girls, forty-four boys). Considering the age of Roma children, twenty-six of them were of preschool age and sixty of school age, while twenty-two were children with development issues. The majority share of Roma children placed in Međimurje County comes from the same county, while eight of them are from neighbouring counties (one child is from Koprivnica-Križevci County, four of them from Varaždin County and three from the city of Zagreb).

Regarding foster families, according to internal data of Čakovec Social Welfare Centre, in 2016 eighty foster families were providing foster care in Međimurje County, out of which fourteen families were of Roma nationality (share of $19 \%$ in the foster families' population). Out of fourteen Roma foster families, six of them live outside of Roma settlements and eight of them in Roma settlements. All Roma foster parents that live in Roma settlements have foster children of Roma nationality.

\section{Research aim and questions}

The aim of the research is to gain an insight into the experience of providing foster care by Roma foster parents to Roma children in Roma settlements. In lieu with the research aim, the following questions were formed:

1. Which circumstances motivated Roma foster families to take up fostering?

2. What are the factors which influence provision of foster care in a Roma settlement?

\section{Research participants and the data collection procedure}

Research wanted to encompass the entire population of Roma foster parents that live in Roma settlements in Međimurje County, i.e. eight foster parents. Seven out of total eight participants from four Roma settlements (five men and two women), aged $38-48$, agreed to participate in the research; most of them have finished primary education. All participants live in matrimony or in domestic partnerships and have children with their spouse or domestic partner. The range of providing foster care was from ten months to 14 years. Only one out of seven participants were involved in kinship fostering. At the time of the research, five participants had two children in placement, one foster parent had one child and one had four children.

The research was conducted in July 2016. Before starting the research, a permission for conducting the research was requested in a written form from the head of the Čakovec Social Welfare Centre. After the permission was given, a social worker who worked in the Foster Care Team at the social welfare centre contacted the participants by phone, explained the aim and the purpose of the research to them and asked their permission to give their phone number to the researcher in order 
to contact them and to arrange the time and place for an interview. Participants who agreed to be contacted by phone were asked for their consent for participation in the research and a place and time for the meeting was agreed. The data was collected via semi-structured interview at the social welfare centre premises and in households of the participants, according to a prepared protocol with questions. The questions referred to circumstances of deciding to become foster care providers, the experience of providing foster care in general regarding life in a Roma settlement, circumstances that were perceived as hindering or empowering in providing foster care. Questions given to the participants:

— How did you decide to become a foster parent?

- What circumstances encouraged you to do so?

— How would you describe your experience in providing foster care?

—What does it mean to you to be a foster care provider in a Roma settlement?

- Are there circumstances that hinder you in providing foster care (related to your own family, biological family of fostered children, your neighbours in Roma settlement, related to the social welfare system, education system)?

- Who supports you in such situations?

- What are the facilitating circumstances that help you in providing foster care in a Roma settlement?

— Do you have anything to add related to your experiences in providing foster care in a Roma settlement?

Additional questions were asked alongside the listed ones to foster care providers in order to deepen given information. The interviews were recorded by a voice recorder with previous permissions given by the participants, and they lasted in average around 30 minutes. The interviews were conducted in Croatian. Before starting the interview, it was verified whether the research participants understood Croatian language and the conclusion was there was no need for Roma language interpreter.

Besides introducing the participants with the aim of the research, they were also informed about ethical aspects of the research implementation, including a guarantee of confidentiality and anonymity in presentation of results. Likewise, the principle of voluntary participation was respected, as well as the right of research participants to refuse to answer questions and to withdraw from the research at any time.

\section{Research method and data analyses}

In lieu with the aim of the research, qualitative approach was chosen because the purpose of the research was to gain a deeper insight into researched phenomenon (foster care experiences of the Roma in Roma settlements), i.e., to describe and interpret experiences, collect new information and gain knowledge and understanding without baseline presumptions (Milas, 2005). Collected data 
was processed by using the thematic analysis procedure. Boyatzis (1998, according to: Žižak et al., 2012) defines thematic analysis as a process of identifying, analysing and reporting according to topics which are recognised within collected data. Thematic data analysis in this paper was done on a semantic level that refers to categorising topics according to participants' statements, and the topics were defined explicitly (Žižak et al., 2012). According to Mirosavljević (2015), the reason for choosing thematic analysis as data processing tool lies in its methodological and theoretical flexibility; it is used to try and summarise the data but not necessarily with a goal to develop a theory. Thematic analysis has shown useful in research questions that do not put social process and circumstances that influence them in its focus, but individual experiences of participants. Transcripts of conversations from the recorder audio files that were submitted for qualitative analysis were made for the purposes of data processing. Thematic analysis process includes: introduction to data, generating initial codes, searching for topics, revising topics, defining and naming topics and writing the report (Braun \& Clarke, 2006).

\section{Results and discussion}

The results were presented via two main thematic areas foreseen by the research framework:

1. circumstances that motivated foster parents to become foster care providers

2. factors which influence the provision of foster care in a Roma settlement.

The listed topics were described by categories and terms which were supplemented in the later text by statements of the research participants.

\section{Circumstances which motivated Roma foster care providers to start providing foster care}

Foster parents, members of the Roma national minority covered by this research, were motivated to become foster care providers by: a desire to provide adequate care to children, existence of conditions for providing foster care and experience with foster care.

Table 1 Verbalised circumstances that motivated Roma foster parents to become foster care providers

\begin{tabular}{|c|c|}
\hline \multicolumn{1}{|c|}{ Categories } & Terms \\
\hline Altruistic reasons & Desire to help children by rescuing them from poverty and bad living conditions \\
\cline { 2 - 2 } Existence of conditions for providing foster care & Desire to provide family to children \\
\cline { 2 - 2 } & Available space in own home for providing foster care \\
\hline \multirow{2}{*}{ Experience with foster care in own family } & One of family members was in foster care or was a foster care provider \\
\cline { 2 - 2 } & Children from extended family were in foster care \\
\hline
\end{tabular}

Research participants listed the aspects of intrinsic motivation, conditioned by altruistic reasons that resulted in a desire to provide help to children, to save them from poverty and miserable living conditions, i.e., to provide help to children in need (...) So that I can somehow help those kids... (1); (...) I wanted to help kids, I see a lot of them living in bad conditions... to have prop'r life, to get schooling 'cause most of them don't 'ave it... (3); (...) Simply to help... starving kid, no interest, no 
care, there's no words... we were motivated by that misery, poverty, famine and hygiene... we couldn't watch it... (5); and a desire to provide a family to children (...) Every kid needs a family... (2). Laklija (2011b) mentions that the motivation for becoming a foster care provider is mostly the intrinsic one, where altruistic motives of foster care providers stand out who want to change the lives of fostered children and to help them and to ensure a stable environment/family for the growth and development of the child (e.g. care for the child's education), as well as give their love to the child, something the research participants mentioned. The results of the Casteel research (2015) conducted on a kinship fostering population of Roma nationality in the city of Zagreb also point to the importance of altruistic motives, but also to a motive for filling out their family budget, something the participants in this research haven't mentioned.

As an incentive for becoming a foster parent, the participants mentioned existence of conditions for providing foster care in their home, and they mentioned they have free space and time for dealing with children (...) We had space, (I) coulda focus on that fostered kids... (2); (...) Everythin' empty ta me... (5). Laklija (2011b) also mentions motives for becoming a foster parent referring to filling out a void, mostly after biological children of foster parents leave their household. The participants of this research mention an existence of empty space and free time for caring about fostered children. They also mentioned the experience of fostering in their own families, i.e. examples from their own family where some family member was or still is a foster parent (...) I got the incentive from my son who was a foster parent... (1) My brother in law was a foster parent... (2); My husband's mom also had one kid...we saw she fostered so we decided... (6); (...) My mother in law...she couldn't be a foster parent anymore because of her age and so I...only because we lived with it...and my brother in law was also a foster parent... (7); or a child from an extended family was placed in a foster family (...) Brother's kids were fostered... (4). Previous experience with foster care, in which we also include acquaintance with already existing foster care providers, present circumstances that can motivate to start providing foster care (Laklija (2011b). According to the participants of this research, an important motivating factor was also an experience of providing foster care by family members, or a member of their extended family being placed in foster care. Sebba (2012) mentions that $35 \%$ of foster parents learn about fostering through the experience of knowing a foster family and $11 \%$ of them had parents who provided foster care. Metcalfe and Humphreys (2002) mention that the experience of knowing foster care providers, besides providing information, also influences the demystification of certain forms of foster care, as well as fostering certain categories of children, which is also the task of developing foster care for the needs of ensuring the rights and welfare of Roma children.

\section{Factors which influence the provision of foster care in a Roma settlement}

From the participants' statements, related to factors which influence the provision of foster care in a Roma settlement, the following can be highlighted: circumstances which hinder fostering for Roma foster parents and those that empower them.

\section{Circumstances that hindered Roma foster care providers in providing foster care}

According to the results, circumstances that hindered Roma foster care providers in providing foster care were their community members' reactions to foster care, behaviour of biological parents 
Mateja Krčar, Maja Laklija: Foster care from the perspective of Roma foster parents in Roma...

of fostered children, behaviour of fostered children, influences from their environment and living circumstances in a Roma settlement.

Table 2 Circumstances that hindered Roma foster care providers in providing foster care

\begin{tabular}{|c|c|}
\hline Categories & Terms \\
\hline \multirow{5}{*}{ Reactions of community members to foster care } & Highlighting material gain for foster care providers \\
\hline & Envy of community members \\
\hline & Lack of support from community members \\
\hline & Reporting foster care providers to the social welfare centre \\
\hline & Inappropriate comments with a purpose to humiliate \\
\hline \multirow{4}{*}{ Behaviour of children's biological parents } & Irresponsible behaviour of parents when being in contact with the child \\
\hline & Parents' resistance towards foster care providers \\
\hline & Threats of parents of fostered children towards foster care providers \\
\hline & Behaviour of parents influenced by the community members \\
\hline \multirow{5}{*}{ Behaviour of fostered children } & Lack of socialisation in children \\
\hline & Problems in child's behaviour \\
\hline & Child's experienced trauma \\
\hline & Influence of biological parents on children \\
\hline & Influence of brothers and sisters on children \\
\hline \multirow{2}{*}{ Life in a Roma settlement } & Noise in the settlement \\
\hline & Possible influence of the community members on children \\
\hline
\end{tabular}

Regarding reactions of community members to foster care, the participants mentioned neighbours maliciously pointing out that they are doing this because of material gain, i.e. in order to get rich on the account of caring for a child (...) That it was because of some money... they were saying why would I do this to myself considering that I already had some material security, I have a house, I have satisfactory life conditions... they said: do you know how much they pay for this... they think to themselves, oh he's rolling in money now he is... (2); (...) Everybody is telling how this is for money only... everybody's asking about that money, you'll be able to do this, you know this, loan that...everybody's complaining, and they all see that misery... (5); (...) That we got rich, that we built all this from these children...that I was getting rich, that I had money... (6). Roma foster parents mentioned community members' jealousy as a hindering circumstance (...) They are jealous not because I'm a foster parent... they're jealous, if they see you doing something, building... they're envious... (3); (...) With Roma women you know how they are, they're jealous... (4); (...) I've 'ad problems ever s'nce I become foster parent... there's envy... (6); and a lack of support from community members (...) At a round table meeting in Zagreb, our community leader got up and started badmouthin' us... 'e was tramplin' us down... (6); (...) We ain't got no support from our Roma neighbours, not even from o'r representat'ves... because they see it, they th'nk we see it as money grub... (7). Regarding reports made to the social welfare centre, they mentioned there were anonymous reports made by community members (...) How can he be a foster parent and has no city plumbing... there was that... (1); (...) First report was immediately the first year... I'm dealing with things in the office and the social worker's phone rings, there's a report, they told her the kids were neglected, hungry, barefoot, different things the worst... I was just there... we weren't sure who made the report... there were always reports like these... I think we got the most reports because we were the first... they even found out that foster parent needs to be employed... I was working last year on a contract, six months doing public works, in two-three days they tipped the centre I wasn't working anymore... because they knew I had'ta have employment... 
(6); (...) We had anonymous tip that we weren't sending kids to normal school, that they were dirty... (7); but also mutual reports from foster parents (...) Foster parents report each other... (5); (...) Foster parents who did the same thing I was went to the centre and would snitch on other foster parents... (7). The participants mentioned, among the reactions of their community members they find hindering, also inappropriate comments that humiliated foster parents or children in foster care (...) They're pissed... they think well why dontcha keep'em in your 'yard... I'd never 'umiliate m'self and raise other's kid ... like he 'ould clean 'other bloke's crap... (2); (...) They said, watcha want kids for, you can make'em, pardon m'French, you've got missus, this that... (5).

Literature shows that one of the sources of problems that foster families face is handling attitudes of the community towards foster care and that the characteristics of the foster parents' environment (local community and neighbourhood) influence the outcomes of foster care (Kregar, 2006; Laklija, 2011a). It is noticeable from the participants' statements that community members in a Roma settlement perceive foster care as a source of money in order to fill in the family budget and that they get no support from community leaders. Vereš (2015a) also points to the community members' attitude and accusing foster parents for a so-called "ethno-business", getting rich on the account of the fostered child. Furthermore, the participants mentioned that the reports made to the social welfare centre hinder their fostering. Vereš (2015a) mentions the same, describing experiences of Roma foster parents who live in Roma settlements who say that they are often, due to envy, anonymously reported for alleged neglect, negligence and bad behaviour towards fostered children. It would be interesting in future research to focus on the content of those reports and social workers' treatments. For example, one of the reports shows that the foster parent himself mentioned that he does not have access to water supply system and the question whether that family fulfils the conditions for providing foster care is put forward. Considering the comments that foster parents mention, i.e. that the goal is to humiliate foster parents, it would be important to also investigate what are the comments to which the children placed in foster families in a Roma settlement are exposed to.

From the behaviour of children's biological parents, who make their foster care placement difficult, the participants mention irresponsible behaviour of parents related to achieving contact with the child, where they list their non-appearance to their meetings with the child. (...) She don't come at all... calls less and less... (1); (...) We would come, she didn't show up... (3); or arriving to a meeting with the child and being under the influence of addictive substances (...) She comes to me drunk... I told her a coupla of times, but ya can't say nothin' to intoxicated person ... if you came to your kid, be at mine, and not by the store drinkin'... I don't allow that... (4); (...) She was drunk, she does things she shouldn't ... got no husband, here today, in Bosnia tomorrow, two days later it's that... drugs are done 'ere... she's taken the little one... because she was, like, drunk... (5). Research participants also mentioned hindering circumstances such as resistance of parents towards foster parents (...) They see us as the enemy ... as if it's our fault the kids were taken from'em ... in the meetings we see they are hostile towards us, they don't wanna communicate as normal people but there's always anger, repression ... there's a lot of resistance... (2); (...) From the beginning she didn't want it to be us, to be in a Roma settlement ... she didn't want to give the kids... (3); (...) Parents watched us as if we were taking those kids, that the centre was taking them on our demand and placing them with us... then the problem is contact ... (7); threats of children's parents (...) Then they provoke us, threaten us, verbal 
threats... it's your fault, you gonna get 'urt, Imma gonna find ya some'here, we'll get 'ven somehow ... (7); and behaviour of parents under the influence of community members (...) They don't want to sign anything, consent for school excursions... people from the settlement are telling them they shouldn't sign anything because they would take their kids permanently... (2).

The results of the research related to the behaviour of biological parents of the fostered child are in line with the research (Sanchirico \& Jablonka, 2000; Ljubotina Družić, Jelača \& Kletečki Radović, 2005) in which foster parents stated that in some cases parents are uninterested in their children while in others they are aggressive in communicating both with children and with foster parents. As for parents' behaviour, the problem of alcohol abuse (Elijah \& Laklija, 2014) is current in Roma settlements, which was mentioned by the research participants as an aggravating circumstance in child and biological parents' meetings, as well as drug dependence. Numerous authors (e.g. Sanchirico \& Jablonka, 2000; Heller, Smyke \& Boris, 2002; DeGarmo, 2014) mention the relationship of foster parents and biological parents of the child as a source of difficulties that foster parents encounter. This difficulty was also mentioned by the research participants through examples of biological parents' resistance and threats to foster parents. Participants also show dissatisfaction regarding the communication with biological parents that is completely absent or extremely rare. The results indicate a need to provide foster parents with support in achieving contact with the child's parents. The participants' statements lead to a conclusion that the parents refuse to participate, namely they refuse to give consent for the child's activities (e.g. going on a field trip), in fear of losing the parental care and to the detriment of the child's best interests, mainly due to the lack of understanding of the way the system functions and under the influence of community members in the Roma settlement. Moreover, the above can also be explained by the fact that the level of literacy among Roma people is generally low, along with an insufficient level of Croatian language (Novak, 2004), which can also cause resistance of parents to sign consents because they are not literate enough to read and understand what they are signing. In addition, the research participants' statements reveal a sentiment of distrust of Roma settlement residents towards the social welfare system, because foster parents are perceived as the ones who report biological parents on which basis the children are taken away and placed in their (foster) family. If we associate this with the earlier finding regarding the regularity of reciprocal reporting among the Roma settlement residents and foster parents, it could be concluded that this also encourages the mentioned parents' attitude. However, this is not the finding of this research and should be examined in contact with biological parents. Research also point to the inevitable conflict that arises from the necessity of collaboration between foster parents and biological parents, because biological parents show resistance and aversion and their anger towards social workers is often projected in their relationship to foster parents (Whiting \& Huber, 2007). All this underlines the importance of educating both foster parents and biological parents about the functioning of the system, their rights, but also their responsibilities in order to protect the child's well-being.

In addition to the biological parents' behaviour, the behaviour of fostered children can also be an aggravating circumstance in providing foster care. This includes the difficulties of children to adapt and the difficulties associated to the functioning of the child in the foster family, which is consistent with many research (e.g. Heller, Smyke \& Boris, 2002; Miron et al., 2013). Concerning the behaviour of fostered children, research participants state that certain characteristics of behaviour 
and previous experiences in the life and growing up of the child also create difficulties in providing foster care. Foster parents stress the lack of socialization in children (...) They didn't know what's toilet, they were afraid... (1); (...) They were afraid of water, didn't know what's flush toilet... they were crying while I was bathing them... he didn't know how to use spoon, fork, knife, nothing, it was tiring for him to eat... didn't speak Croatian... (3); manifestation of behavioural disorders (...) Glass must be there, he'll knock it over on purpose... (5); (...) He was a handful, showed a lot of those behaviour flaws... stealing... (7); and the child's experiences associated to traumas it was exposed to in the family (...) She had scars on eyes, she used to put out cigarette buts on her arms, eyes... (1); (...) These are tragedies what he told us, what they went through... when they tell me that, gives me the creeps... it's trauma for them... (3). The aggravating influence of the social environment in providing foster care, according to the research participants' statements, is the influence of the biological parents on the fostered child (...) He behaves unnatural when comes back from biological family, cries, wants to go back... I talked to social worker and all of them... guess it's that kind of enthusiasm when you're with your parents and then they giving everything to you, buy it all ... and kid as he is, it's easy to buy him... (2); (...) Dad promises world to him... they promise everything in meetings, you come back home, we have this ready for you, these toys, rooms like this, then the kids hesitating... (7); and the influence of siblings on fostered children (...) has half-sister, that half-sister stop her on way to school four-five times... and then used opportunity and convincing her to do stupid things... come on, take wallet from that mister, do this, that... so half-sister convinced her to tell bad things about us and she did, and it ain't true... she admitted later that sister convinced her to do that... (7).

As far as children are concerned, the participants said that children with behavioural disorders create difficulties, which is also recognized in literature (Laklija, 2011a), where it is mentioned that children with behavioural disorders can be a special challenge for foster parents to cater for their needs. Children who come to foster families may have different complex, social, emotional and behavioural difficulties that hinder their adaptation to a new family environment (Škrbina, 2010). Likewise, the participants mentioned that children experienced traumatic events in their primary family. It is known that some children placed in foster families in Croatia have experienced long-term exposure to multiple stressful events including alcohol abuse in the family, physical and psychological abuse and neglect, and often they were separated too late from their primary families to prevent the consequences to their psychophysical functioning (Kletečki Radović \& Kregar Orešković, 2005). Furthermore, foster parents also mention the so-called negative impact of contact with biological parents on the child's behaviour after the contact is over. Dugan (2014) states that children often change their behaviour after their encounter with the parents due to the renewal of memories and emotions that are linked to loss and sorrow, but also due to their parents' unrealistic promises that cannot be realized and that create false hope in children (they are unrealistically talking about leaving foster parents and returning to their parents, they tend to idealize their parents and unrealistically admit their influence, etc.).

According to foster parents' statements, life in a Roma settlement is also one of the circumstances that makes foster care harder. As aggravating circumstances, the participants mention noise in the settlement (...) Noise, music... (5); and probable influence of community members and their lifestyle on fostered children (...) My kids ain't hanging out with folks from the settlement, I ain't letting them... (1); (...) I don't let them wander around, like, go to our settlement... (2); (...) Cause 
here kids smoking from small age, most using alcohol...cause you know, kids copy parents...cause you see Roma lifestyle and know with who your kid might hang out, my kids ain't hanging out with just anyone... (4); (...) Here in settlement always alcohol, drugs... (5). According to Šućur (2004), the above-mentioned problem of alcoholism and various forms of socially unacceptable behaviour are present in Roma settlements. In this context, research participants consider there is a risk for the child to start smoking and drinking as early as in elementary school as a result of learning patterns of behaviour from parents and other community members, also including the risk of drug abuse. As can be seen from some of the research participants' statements, part of foster parents forbids the child to go to the settlement or to socialise with children from the settlement in fear of possible negative influences. This raises the question of whether, according to the participants' statements and related to the perceived risks for the child in some Roma settlements, it is really in the child's best interest to be placed in a foster family in a Roma settlement in order to ensure the child's right to preserve religious, cultural and/or ethnic identity.

\section{Empowering circumstances for foster parents of Roma nationality in providing foster care}

As empowering circumstances in providing foster care, the research participants listed the support provided to them, the so-called emotional "effects" of foster care and life in a Roma settlement.

Table 3 Empowering circumstances for foster parents of Roma nationality in providing foster care

\begin{tabular}{|c|c|}
\hline \multicolumn{1}{|c|}{ Categories } & Terms \\
\hline \multirow{4}{*}{ Support } & Family support \\
\cline { 2 - 2 } & Support of friends and community members \\
\cline { 2 - 2 } & Support of social workers \\
\cline { 2 - 2 } & Support of non-profit organizations \\
\cline { 2 - 2 } & Media support \\
\hline \multirow{2}{*}{ Emotional "effects" of foster care } & Education system support \\
\cline { 2 - 2 } & Retional fulfilment achieved in providing foster care \\
\hline \multirow{2}{*}{ Life in a Roma settlement } & Proximity of the child to Roma culture and language \\
\cline { 2 - 2 } & Roma community lifestyle \\
\cline { 2 - 2 } & Future of children in a Roma settlement \\
\cline { 2 - 2 } &
\end{tabular}

The participants stated that they feel empowered by their family support (...) Mostly it's support, talking to my wife... (2); (...) For example, grandma, brothers, relatives... (5); (...) Family... (7); support of friends and community members (...) People in village, Croatians, and also Roma... (2); (...) Our friends... (3); (...) Positive things they're sayin'... better you do it than someone else, giving me a bit of support, like, it's ok... (4); support of social workers (...) Then social worker stood up for us... I had support from all social workers... (6); (...) We have support from social welfare centre... (7); support from non-profit organizations (...) And in these kind of meetings of foster parents we talk about our experiences, it's easier when we sayin' something to someone and simply get support there and some kind word... (2); (...) We have foster parents association... their moral support... (7); media support (...)

They really commended us in media, newspaper... (7); and education system support (...) I talked to school principle, he got it all... they're accepted... (1); (...) In school and all that, colleagues on every day basis and also in educational centre... (2). Research participants cite various sources of social 
support. They mentioned family support, which, according to literature, represents the primary and most common source of social support (Dobrotić \& Laklija, 2012), support of friends, support of community members, support of non-profit organizations, media support and support of social welfare and education system. Correspondingly to the findings of this research, Vereš (2015b) also points to the satisfaction of Roma children foster parents in Međimurje County regarding the acceptance of the children in their surroundings and in primary and secondary schools. The importance of social support is reflected in the fact that it can mitigate the negative impact of stress, improving the ability of the person to face the stressor, meaning that a person can more effectively face the increased demands of a particular situation when other people are available to provide different forms of assistance, especially emotional one (Pećnik \& Raboteg Šarić, 2005). This theoretical hypothesis explains the significance of social support when facing circumstances that hinder providing foster care in Roma settlements.

As an empowering factor, foster parents also indicate emotional "effects" of foster care, that is, emotional fulfilment achieved through providing foster care (...) Cause I know I helped someone... that's love... (5); (...) I can say I made it... I'll be grateful... (6); (...) That's my biggest reward... (7); and close relationships within the family, i.e. close bonds with fostered children (...) I'm his mother... he calls me mom... (3); (...) Kids call me dad, call her mom... sayin he's his brother... considers him brother... (6). The mentioned emotional "effect" of foster care can be related to their intrinsic motivation, more specifically, to the altruistic motive to become a foster care provider. Although in the context of this research we cannot draw conclusions on the correlation between foster parents' motivation and their satisfaction with the role of foster parents, MacGregor et al. (2006) argue that the intrinsic motivation of foster parents is highly correlated with their satisfaction with providing foster care and maintaining their role as foster care providers. The foster parents' statements show the importance they assign to the emotional part, related to creating an affectionate relationship with the fostered child and achieving closeness with the child. On the other hand, the challenge that foster parents face relates to creating opportunities to develop attachment between the child and the foster family while at the same time respecting and retaining the relationship of attachment and identification with biological parents. In this context, a social worker should assist both foster parents and the child in coping with emotions associated with the biological family of the child. Foster parents should be educated about the way the child will address them. Namely, since they do not exercise the right to parental care for the fostered child and since the child has its biological parents, foster parents should not encourage or allow the child to address them as "mom" or "dad" (Dugan, 2014). Foster parents are not the child's parents, and in that context, the effects on the child and his biological family when the child addresses foster parents mom or dad should be problematised (in contact with them during education, but also during the period of providing foster care).

Even though the participants recognized living in a Roma settlement as an aggravating circumstance in providing foster care, they also mentioned it as an empowering circumstance due to the importance of preserving the culture and the language, but also the future of fostered children. In this context, the research participants stress the proximity of the child to the Roma culture and language (...) For preserving culture and language, all these, say, good sides... (2); (...) Culture connects us... (5); (...) That's our tradition, our culture... language... it's advantage in Roma village... they have 
to speak mother tongue, that can't be abandoned just like that... (6); (...) Still it's easier for them to have Roma friends, for the language... (7); the lifestyle in Roma community (...) Kids are happier to be in Roma settlement, hang out cause we're used to living in community... our kids are used to live in company... (6); and the future of children fostered in a Roma settlement concerning their return to the family (...) After some years kids still go back home, cause your home's your home... (3); (...) After turning 18 normally again in the settlement... (5). The participants of this research, as well as Roma foster parents in Vereš's research (2015a), said that they consider it is better for Roma children to grow up in Roma foster families because they remain in their culture, use native language and feel more secure in that environment.

\section{Research limitations}

The findings of this research should be interpreted bearing in mind the research context and its limitations. One of the methodological limitations is linked to the fact that all research participants are from the same region, so it would be good to extend the number of participants in further research to the entire Croatian territory, given the existing regional differences in foster care in the Republic of Croatia. It would be useful to include associations as mediators in approaching the research participants, to reduce the amount of socially desirable responses the participants might have given because they were contacted by social workers from the relevant social welfare centre. Moreover, the very place where interviews were held might have led the research participants to provide socially desirable responses. Namely, part of the interviews was conducted in the Social Welfare Centre premises, and part within the foster families. The limitations stemming from the conducted semi-structured interviews are related to the possibility that perhaps not all of the relevant aspects of the research questions have been covered and should be further developed in future research. During some of the interviews, it was necessary to verify the understanding of questions asked to the research participants. Before conducting the interview, it was verified that all the participants speak Croatian and it was determined that there is no need for a Roma language interpreter. However, the question remains whether a possible limitation connected to the understanding of the question or the possibility of expressing themselves in Croatian influenced the collected data, specifically the content, the level of insights gained and the duration of the interview. This aspect should be given special attention in future research. The interview was conducted by a person coming from the region where the research was conducted and speaking the Međimurje dialect. With respect to the method/technique used for conducting the research, that is, the application of a semi-structured interview, it would be important also to apply other methods and techniques in future research, such as focus groups with participants, case research, etc. In regard to the researcher position, special attention was paid to ensure that the researchers are in no way connected to the participants, and to raise awareness about the researchers' partiality and position with respect to the research subject in order to prevent their influence on the data collection process and on the interpretation of obtained data. In order to ensure credibility, the research was conducted by an impartial researcher. In the course of data processing, the concepts, categories and topics were discussed from two research perspectives, in order to verify consistency. 


\section{Final considerations}

The contribution of this research is in the orientation to the beneficiary perspective of Roma foster parents. The obtained results provide a better understanding of the experiences of Roma foster parents living in Roma settlements, based on which further activities can be planned, both in terms of providing support to families (biological and foster ones) and children in foster care and in terms of recruiting and educating new foster families. The results obtained in this research have shown that foster parents belonging to the Roma national minority were motivated to become foster care providers primarily due to their desire to provide adequate care to children in need, which they consider as a way of saving them from a situation of poverty and bad living conditions, and their desire to provide assistance to the family. As other motives, they indicated existence of conditions for providing foster care, which include having the available space and time to care for the children, as well as a foster care experience within their own families. As hindering circumstances in providing foster care, the participants listed various reactions by community members to foster care (accusations for acquiring material gain, envy, lack of support, reporting to the social welfare centre and inappropriate comments), the behaviour of biological parents of the fostered children (irresponsible behaviour in contact with the child, resistance and threats toward foster parents and behaviour under the influence of community members), the child's behaviour (lack of socialisation, behavioural disorders, coping with trauma and influence of parents and siblings on the child) and life in a Roma settlement (noise in the settlement and possible negative influence on the child). These factors give clear guidelines to what activities the social policy system should focus on, in line with the work of the mentioned strategies and documents, as well as experts from social welfare centres, civil society organisations and the competent ministry. Furthermore, the research results show some potentially new research areas, topics and aims that would be worth deepening (such as accusations for the so-called "ethno-business", attitudes of patriarchs/elders in Roma settlements toward foster care, reporting to social welfare centres, foster care experience from the perspective of parents and children, etc.).

As empowering circumstances in providing foster care, the participants cited social support, the so-called emotional "effects" of providing foster care on foster parents and life in a Roma settlement, which they mention also as an empowering circumstance precisely because of the culture, the language the children share with their neighbours and the sense of belonging of the fostered children to the Roma community. The results indicate the recognized importance of preserving the child's cultural identity and the need to inform and familiarise the Roma people with foster care, with the conditions they need to meet in order to become foster parents and with positive examples of foster parents and life stories of fostered Roma children, all with a view to sensitise and motivate Roma families to engage in providing foster care and to improve the quality of child care. The ways to achieve this include organising public panel discussions in Roma settlements and public services available to Roma families. In addition, it is important to educate members of Roma national minority about the functioning of the foster care system and to inform parents of children separated from the family about their rights and responsibilities, as well as on their role in the life of the child after the separation. Moreover, through cooperation between the competent ministry, social welfare centres, international organisations and associations acting in the field of foster care and beyond, it is necessary to provide Roma foster families with support and education 
in coping with the attitudes of the social environment, with the behaviour of parents and children and other challenges associated with providing foster care, all in order to ensure protection and quality care for the fostered child. Regarding the promotion of foster care, the results indicate the importance of establishing contact with the elders in Roma settlements which act as authority figures, as well as with Roma associations.

The data obtained in this research did not provide us with a lot of insight into how foster parents provide foster care and/or what are their experiences in providing foster care (for instance, in terms of foster parent-child relationship, impact on their family dynamics, etc.), but instead the obtained data presented the circumstances surrounding this experience. We gained insight into the context within which foster parents provide foster care, rather than into their concrete experience of providing foster care for the needs of a specific child. Scientific research and scientific and professional papers on the experiences of fostered Roma children or foster Roma families are rare and would provide significant backing in improving the practical activities and raising the quality of foster care for Roma children in line with the Roma tradition and culture. Research on this topic would be interesting due to the very specificity of the Roma tradition and the way they perceive the notion of foster care, as well as the way in which foster parents are recruited. Therefore, it would be useful to conduct further research within the population of Roma foster parents in other geographical areas of the Republic of Croatia. Moreover, it would be interesting to research whether there are any differences between providing foster care in Roma settlements and outside, so the research could include Roma foster parents not living in a Roma settlement, but also the children placed in foster care. Additionally, it would be interesting to conduct a longitudinal study focusing on life circumstances and educational outcomes of Roma children raised in Roma foster families, comparing their experiences with the experiences of Roma children raised in foster families belonging to the majority population or in institutions and vice versa. 


\section{References}

Anghel, R., Herczog, M. \& Dima, G. (2013). The challenge of reforming child protection in Eastern Europe: The case of Hungary and Romania. Psychosocial Intervention, 22, 239-249.

Braun, V. \& Clarke, V. (2006). Using thematic analysis in psychology. Qualitative Research in Psychology, 3(2), 77-101.

Brooks, D., James, S. \& Barth, R.P. (2002). Preferred characteristics of children in need of adoption: Is there a demand for available foster children. Social service review, 76(4), 575-602.

Casteel, V. (2015). Iskustva srodničkih udomitelja romske nacionalne manjine [Experiences of Roma kinship foster parents]. Neobjavljeni diplomski rad. Zagreb: Pravni fakultet Zagreb, Studijski centar socijalnog rada.

Committee on the Elimination of Racial Discrimination (2015). The Ombudsman for Children in Norway's supplementary report to Norway's combined twenty-firstandtwenty-second periodic report on the International Convention on the Elimination of all forms of Racial Discrimination (CERD). Downloaded from: http://tbinternet.ohchr.org/Treaties/CERD/ Shared\%20Documents/NOR/INT_CERD_IFN_NOR_20996_E.pdf (20.10.2016.)

D'Arcy, K. \& Brodie, I. (2015). Roma Children and Young People in Bulgaria: Patterns of Risk and Effective Protection in Relation to Child Sexual Exploitation. Social Inclusion, 3(4), 1-9.

Daugherty Bailey, J. \& Schmidt, V. (2014). Institutionalization of Children in the Czech Republic: A Case of Path Dependency. Journal of Sociology \& Social Welfare, 41(1), 53-75.

DeGarmo, J. (2014). Stalking and Other Dangers Facing Foster Parents. Downloaded from: http:// www.ifapa.org/pdf_docs/WeeklyWordJune242014.pdf (15.10.2016.)

Dobrotić, I. \& Laklija, M. (2012). Obrasci društvenosti i percepcija izvora neformalne socijalne podrške u Hrvatskoj [Patterns of sociability and perception of informal social support in Croatia]. Društvena istraživanja, 115(1), 39-58.

Dugan, I. (2014). Važnost kontakata između udomljene djece i bioloških roditelja [The importance of contacts between foster children and biological parents]. In D. Grujić (ur.), Internacionalna konferencija: Izazovi hraniteljstva na početku 21. veka - iskustva koja kreiraju budućnost (str.153-162). Beograd: Centar za porodični smeštaj i usvojenje Beograd.

Družić Ljubotina, O., Jelača, N. \& Kletečki Radović, M. (2005). Socio-demografska obilježja i iskustva udomiteljskih obitelji [Socio-demographic characteristics and experiences of foster families]. Ljetopis socijalnog rada, 12(1), 89-106.

Elijaš, M. \& Laklija, M. (2014). Iskustvo rada socijalnih radnika s romskim obiteljima [Work Experience of Social Workers with Roma Families]. Socijalne teme, 1(1), 115-134.

Family, Child, Youth Association (2014). Children in conflict with the law - Report on the outcomes of the qualitative research conducted in Hungary. Downloaded from: http://www.eurochild. org/fileadmin/public/06_Projects/Past/Alternatives_to_custody/qualitative_report_hungary.pdf (20.10.2016.)

Forum za kvalitetno udomiteljstvo (2014). 7. Nacionalni susret udomiteljskih obitelji za djecu Sv. Martin na Muri [7th National Meeting of foster families for children in St. Martin na Muri]. Downloaded from: http://www.udomiteljizadjecu.hr/arhiva/prenosimo/7-nacionalni-susret-udomiteljskih-obitelji-za-djecu-sv-martin-na-muri (20.10.2016.)

Heller, S., Smyke, A.T. \& Boris, N.B. (2002). Very young foster children and foster families: Clinical challenges and interventions. Infant Mental Health Journal, 23, 555-575. 
Kennedy, J., Kukk, K. \& Mansens, R. (2010). Children in alternativne care. National surveys. EuroChild Secretariat. Downloaded from: https://www.eurochild.org/fileadmin/public/05_Library/ Thematic_priorities/06_Children_in_Alternative_Care/Eurochild/Eurochild_Publication_-Children_in_Alternative_Care_-_2nd_Edition_January2010.pdf (20.10.2016.)

Kletečki Radović, M. \& Kregar Orešković, K. (2005). Kvalitativna analiza iskustva udomitelja [Qualitative analysis of foster parents' experience]. Ljetopis socijalnog rada, 12(1), 67-88.

Konvencija o pravima djeteta [Convention on the Rights of the Child], Državni zavod za zaštitu materinstva i mladeži, Zagreb, 2001.

Kregar, K. (2004). Socijalna podrška djece smještene u dječjim domovima i udomiteljskim obiteljima u Republici Hrvatskoj [Social support of children placed in children's homes and foster families in the Republic of Croatia]. Ljetopis socijalnog rada, 11(2), 229-248.

Laklija, M. (2009). Psihosocijalna obilježja udomitelja i iskustvo udomiteljstva djece [Psychosocial characteristics of foster parents and their fostering experience]. Doktorska disertacija. Zagreb: Pravni fakultet Sveučilišta u Zagrebu, Studijski centar socijalnog rada.

Laklija, M. (2011a). Pristupi udomiteljskoj skrbi za djecu u svijetu i čimbenici koji utječu na ishode udomiteljstva [Approaches to Foster Care of Children in the World and Factors That Promote or Inhibit Successful Fostering of a Child]. Revija socijalne politike, 18(3), 291-309.

Laklija, M. (2011b). Doprinos socio-demografskih i psihosocijalnih obilježja udomitelja objašnjenju motiva za bavljenje udomiteljstvom djeteta [Contribution of foster parents' socio-demographic and psychosocial characteristics in explaining foster parents' motives for providing foster care to children]. Ljetopis socijalnog rada, 19(1), 119-144.

Laklija, M., Blažeka Kokorić, S. \& Žabarović, I. (2016). How to improve protection of children's rights to family life? - Difficulties in realisation of out of institution care for children with specific risks. Sofia: SGEM, Book 2, Volume I, 679-688.

Laklija, M. \& Sladović Franz, B. (2013). Individualni plan skrbi za dijete u udomiteljskoj obitelji [Individual care plan for a child in a foster family]. Zagreb: Sirius - Centar za psihološko savjetovanje, edukaciju i istraživanje (priručnik).

MacGregor T. E., Rodger S., Cummings A. L. \& Leschied A. W. (2006). The Needs of Foster Parents, A Qualitative Study of Motivation, Support, and Retention. Qualitative Social Work, 5(3), 351-368.

Marčac, T. (2014). Udomiteljstvo romske djece u neromskim obiteljima. Diplomski rad. Zagreb: Pravni fakultet, Studijski centar socijalnog rada.

McFadden, E.J. \& McNitt, M. (2008). Children Without Parental Care: The International Foster Care Organization's Response - "Building A Foster Care Community.". Downloaded from: http://www.nacsw.org/Publications/Proceedings2008/McFaddenEChildren.pdf (20. 10. 2016.)

McGaughey, F, Curran, S, Fay, R, Nurse, D \& Garland, P. (2012). Roma Communities in Ireland and Child Protection Considerations. Downloaded from: http://www.PaveePoint.ie/wp-content/uploads/2013/10/Roma-Communities-in-Ireland-and-Child-Protection-Considerations.pdf (20. 10. 2016.)

Metcalfe, F. \& Humphreys, C. (2002). Fostering Action Research and Action Research in Fostering. Qualitative Social Work, 1(4), 435-450. 
Milas, G. (2005). Istraživačke metode u psihologiji i u drugim društvenim znanostima [Research methods in psychology and other social sciences]. Jastrebarsko: Naklada Slap.

Ministarstvo zdravstva i socijalne skrbi (2010). Plan deinstitucionalizacije i transformacije domova socijalne skrbi i drugih pravnih osoba koje obavljaju djelatnost socijalne skrbi u Republici Hrvatskoj 2011. - 2016. (2018.) [The Plan for Transformation and Deinstitutionalization of Social Welfare Homes and Other Legal Entities Providing Social Welfare Services in Croatia for the period 2011 - 2016 (2018)]. Zagreb: Ministarstvo zdravstva i socijalne skrbi.

Miron, D., Bisaillon, C., Jordan, B., Bryce, G., Gauthier, Y., St-Andre, M. \& Minnis, H. (2013). Whose Rights Count? Negotiating Practice, Policy, and Legal Dilemmas Regarding Infant-Parent Contact When Infants are in Out-of-Home Care. Infant mental health journal, 34(2), 177-188.

Mirosavljević, A. (2015). Izvansudska nagodba - perspektiva oštećenika i mladih u sukobu sa zakonom [Out-of-court settlement: perspective of victims and youth in conflict with the law]. Doktorska disertacija. Zagreb: Pravni fakultet, Sveučilište u Zagrebu, Studijski centar socijalnog rada.

Morgan, K. \& Baron, R. (2011). Challenging behaviour in looked after young people, feelings of parental self-efficacy and psychological well-being in foster carers. Adoption \& Fostering, 35(1), 18-32.

Nacionalni program za Rome [The Croatian National Programme for the Roma] (2003). Zagreb: Vlada Republike Hrvatske.

Nacionalna strategija za prava djece u Republici Hrvatskoj za razdoblje od 2014. do 2020. godine [National Strategy on the rights of children, 2014 - 2020] (2014). Zagreb: Vlada Republike Hrvatske, Ministarstvo socijalne politike i mladih.

Nacionalna strategija za uključivanje Roma, za razdoblje od 2013. do 2020. godine [National Roma inclusion strategy from 2013 to 2020] (2012). Zagreb: Vlada Republike Hrvatske, Ured za ljudska prava i prava nacionalnih manjina.

Novak, J. (2004). Romska zajednica i međunarodne institucije: tek relativan uspjeh zaštite ljudskih i manjinskih prava [The Roma Community and International Institutions: Only Relative Success in the Protection of Human and Minority Rights]. Migracijske $i$ etničke teme, 20(4), 403-432.

O'Higgins, K. (1993). Travelling children in substitute care, Protecting the Cultural Identity of Gypsy, Roma and Traveller Children, Surviving childhood adversity. Belfast: Institute of Irish Studies.

Pećnik, N. \& Raboteg-Šarić, Z. (2005). Neformalna i formalna podrška jednoroditeljskim i dvoroditeljskim obiteljima [Informal and Formal Support to One-Parent and Two-Parent Families]. Revija za socijalnu politiku, 12 (1), 1-21.

Rosenfield, E. (2010). Combating Discimination against the Roma in Europe: Why Current Strategies Aren't Working and What Can Be Done. Topical Research Digest: Minority Rights. Downloaded from: https://www.du.edu/korbel/hrhw/researchdigest/minority/Roma. pdf (25. 10. 2018.)

Sanchirico, A. \& Jablonka, K. (2000). Keeping Foster Children Connected to Their Biological Parents: The Impact of Foster Parent Training and Support. Child and Adolescent Social Work Journal, 17(3), 185-203. 
Sebba, J. (2012). Why do people become foster carers? Oxford: University of Oxford, Rees Centre for Research in Fostering and Education.

Sirius - Centar za psihološko savjetovanje, edukaciju i istraživanje (2017). Analiza sustava skrbi za djecu u zajednici i udomiteljstva za djecu. Analiza potreba za dodatnim osposobljavanjem pomoćnih odgajatelja, odgajatelja i udomitelja, s posebnim naglaskom na transverzalne vještine, završni izvještaj [Analysis of the Child Care system in Community and Foster Care System. Analysis of the need for additional training of assistant teachers, educators and foster parents, with a focus on the transversal skills, the final report]. Downloaded from: http://centar-sirius.hr/-/1880-2/ (20.10.2018.).

Smith Rotabi, K. \& Hübinette, T. (2017). Orphaned and Vulnerable Romany Children and their Protection: Child Adoption, Foster Care, and Child Rights. Downloaded from: https://ddd. uab.cat/pub/afin/afinENG/afin_a2017m6n95iENG.pdf (10. 10. 2018.)

Sweeney, S. \& Matthews, Z. (2017). Friends, Families and Travellers: A guide for professionals working with Gypsies, Roma and Travellers in Children's Services. Downloaded from: https://www. gypsy-traveller.org/wp-content/uploads/2017/03/A-guide-for-professionals-workingwith-Gypsies-and-Travellers-in-the-public-care-system.pdf/ (10. 10. 2018.)

Šikić-Mićanović, L., Ivatts, A. R., Vojak, D. \& Geiger-Zeman, M. (2015). Socijalno uključivanje djece Roma (RECl+) - Izvještaj za Hrvatsku. [Roma Early Childhood Inclusion(RECl+) - Croatia Report] Zagreb: Fondacije Otvoreno društvo (OSF), Fond za obrazovanje Roma (REF) $i$ UNICEF.

Škrbina, D. (2010). Podrška udomitelja koji udomljavaju djecu s Down sindromom [Foster family support for child with Down syndrome]. Život i škola, 23(1), 9-34.

Šućur, Z. (2004). Utjecaj sociodemografskih čimbenika na poimanje romskog roditeljstva i odrastanja [The Effects of Sociodemographic Background on the Conception of Gypsy Parenting and Growing Up]. Društvena istraživanja, 13(4-5), 843-865.

Vandekereckhove, A. (2011). Respect of the rights of children \& young people living in institutional care: state of play. European Network of Ombudspersons for Children. Downloaded from: $h$ ttp://enoc.eu/wp-content/uploads/2015/02/2011-ENOC-report-on-children-ininstit-care.pdf (20. 10. 2016.)

Vereš, S. (2015a). Velika vrijednost romskih udomiteljskih obitelji u Međimurskoj županiji [The great importance of Roma foster families in Međimurje County]. Sretno dijete, 9(1), 3.

Vereš, S. (2015b). Specifičnosti udomiteljstva djece romske nacionalnosti iz perspektive CSS-a [Specificity of foster care of Roma children from the perspective of SWC]. Sretno dijete, 9(1), 8-11.

Vijeće Europe (2012). Human rights of Roma and Travellers in Europe. Downloaded from: https:// www.coe.int/t/commissioner/source/prems/prems79611_GBR_CouvHumanRightsOfRoma_WEB.pdf (20. 10. 2016.)

Whiting, J. B. \& Huher P. L. (2007). Significant stress and real rewards: The ecological and ambiguous experiences of foster parents. Relational Child \& Youth Care Practice, 20(2), 9-20.

Vlada Republike Hrvatske (2012). Nacionalna strategija za uključivanje Roma, za razdoblje od 2013. do 2020. godine [National Strategy on the rights of children, 2014 - 2020]. Downloaded from: $h$ ttp://www.zagreb.hr/UserDocs/mages/arhiva/Nacionalna\%20strategija\%20 za\%20uklju\%C4\%8Divanje\%20Roma\%202013-2020.pdf (23. 9. 2017.) 
Žižak, A. (2008). Udomiteljstvo djece u Hrvatskoj: analiza stanja i prijedlog smjernica [Foster Care for Childrean in Croatia, Analysis of the State of Art and Recomedation of Policy Development]. Zagreb: Ured UNICEF-a za Hrvatsku.

Žižak, A., Koller-Trbović, N., Jeđud Borić, I., Maurović, I., Mirosavljević, A. \& Ratkajec Gašević, G. (2012). Što nam djeca govore o udomiteljstvu: Istraživanje dječje perspektive udomiteljstva u Hrvatskoj s preporukama za unapređenje [What do Children Say About Foster Care - childrens perspective of foster care with recommendations]. Zagreb: Ured UNICEF-a za Hrvatsku. 


\title{
Udomiteljstvo iz perspektive udomitelja Roma u romskim naseljima u Međimurskoj županiji
}

\author{
Mateja Krčar \\ Centar za socijalnu skrb Čakovec
}

Maja Laklija

Pravni fakultet Sveučilišta u Zagrebu, Studijski centar socijalnog rada

\begin{abstract}
Sažetak
Udomiteljstvo je jedan od oblika skrbi za djecu koji se javlja kao alternativa institucionalnom zbrinjavanju djece, a njegova je prednost upravo u činjenici obiteljskog okruženja. Cilj ovog istraživanja bio je dobiti uvid u iskustva udomitelja pripadnika romske nacionalne manjine ( $\mathrm{N}=7$ ) u pružanju udomiteljske skrbi za djecu u romskim naseljima u Međimurskoj županiji. Dobiveni rezultati pokazuju da je romske udomitelje na udomiteljstvo potakla želja za pružanjem primjerene skrbi djeci, postojanje uvjeta za bavljenje udomiteljstvom, kao i iskustvo udomiteljstva u vlastitoj obitelji. Sudionici u ovom istraživanju kao otežavajuće okolnosti u pružanju udomiteljske skrbi navode razne reakcije sumještana na njihovo bavljenje udomiteljstvom, ponašanje bioloških roditelja djece, ponašanja djece te život u romskom naselju zbog specifična načina života Roma. Osnažujuće okolnosti u pružanju udomiteljske skrbi su: socijalna podrška, tzv. emocionalni 'efekti' udomiteljstva na udomitelje kao i život u romskom naselju zbog očuvanja kulture, jezika i pripadnosti. Praktična je implikacija istraživanja produbljivanje razumijevanja ovoga tematskog područja, a rezultati, osim za promišljanje o budućim istraživanjima, pružaju smjernice za praktično djelovanje na razini poboljšanja kvalitete skrbi i brige za romsku djecu u udomiteljskoj skrbi te unapređenju podrške romskim udomiteljima u skladu s njihovom tradicijom i kulturom.
\end{abstract}

Ključne riječi: udomiteljstvo, djeca, socijalna skrb, romske obitelji, romsko naselje

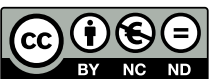

Međunarodna licenca / International License:

Creative Commons Attribution-NonCommercial-NoDerivatives 4.0. 